\title{
Nitridation of Silicon Powder
}

\author{
By \\ Yoshizo INOMATA \\ (National Institute for Researches in Inorganic Materials)
}

\section{Introduction}

Nitridation process of highly pure silicon powder was reported to follow linear kinetics ${ }^{1,2)}$, and the rate determining step was considered to be diffusion process of nitrogen atom through nitrided surface skin built on silicon particles ${ }^{2,3)}$. From the linear kinetics, those nitride skin was considered to repeat cracking and exfoliation during the reaction ${ }^{2,3}$. The reaction rate was roughly proportional to the square root of particle diameter of silicon's. The cause of the size effect, however, was left uncertain. A purpose of this report is to discuss the reaction process referring to the microstructure of reaction products.

\section{Experiments}

Highly pure and fine powder of silicon (average grain size; ca. $2 \mu \mathrm{m}$, purity $>99.999 \%$ ) and commercially pure nitrogen $\left(\mathrm{O}_{2}<0.5 \mathrm{ppm}\right.$, dew point $<$ $-60^{\circ} \mathrm{C}$ ) were used as reactants. Electron micro-

a)

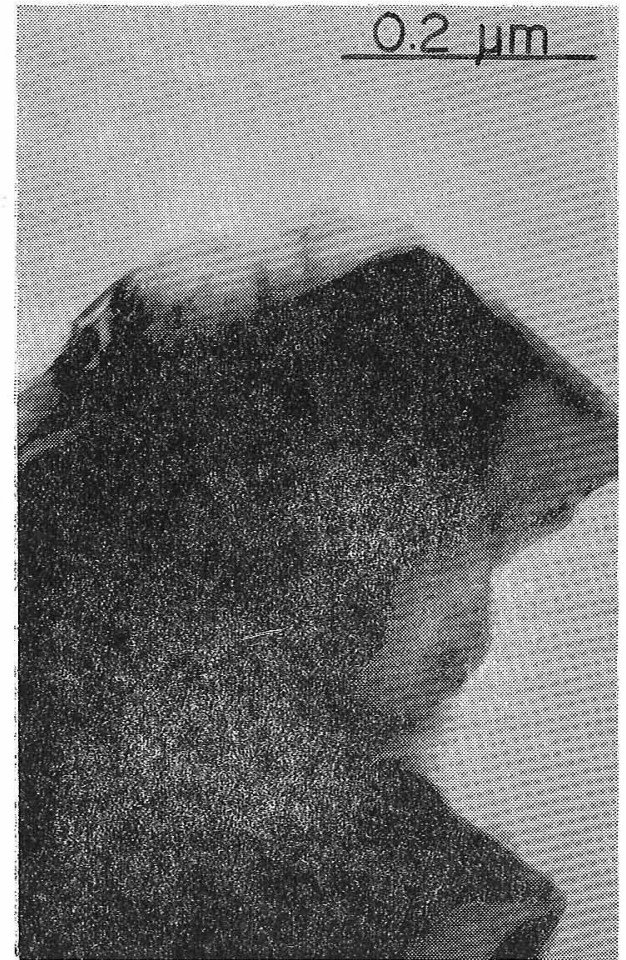

graphs of the raw silicon powder are shown in Fig. 1. One gram of silicon powder was moisten with distilled water and pressed in to a disk, $15 \mathrm{~mm}$ in diameter and ca. $4 \mathrm{~mm}$ in thickness. Average porosity of the pressed disks was ca. 39 40\%. They were nitrided in a tubular furnace at $1220^{\circ}, 1270^{\circ}$ and $1410^{\circ} \mathrm{C}$ for about $3 \mathrm{~h}$ in nitrogen stream of 1 atmospheric pressure.

Fractions of nitrided silicon were calculated from the weight increment, and they were ca. 10, 20 and $90 \%$, respectively. Microstructure of the samples were studied with electron microscopes.

\section{Resuits}

Microstructures of fracture surface of the nitrided samples are shown in Fig. 2 4. In the sample nitrided at $1220^{\circ} \mathrm{C}$, initial outline of raw silicon powder still remained and silicon grains were lightly covered with fluffy reaction products as shown in Fig. 2-(a). Very thin, $100 \sim 200 \AA$ thick products

b)

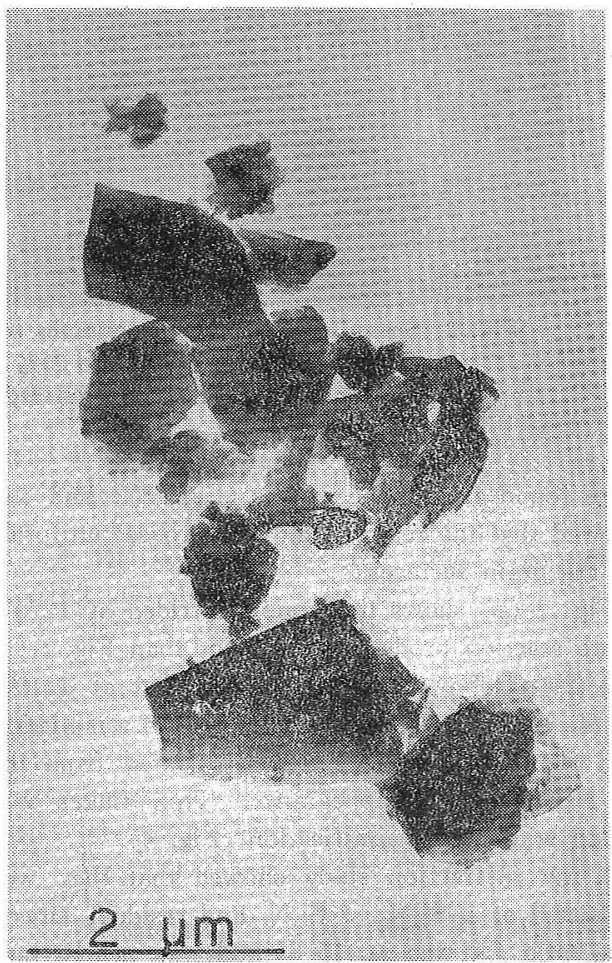

Fig. 1 Electron micrographs of raw silicon powder. 
a)

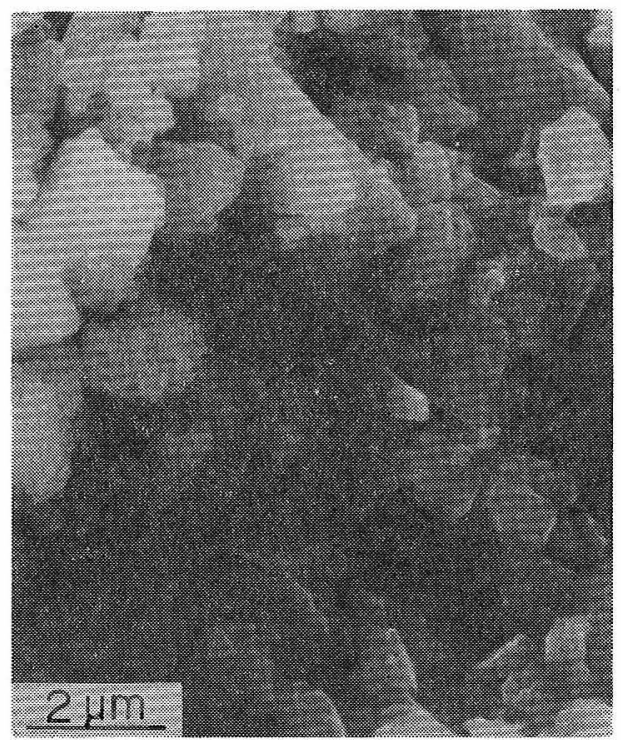

c)

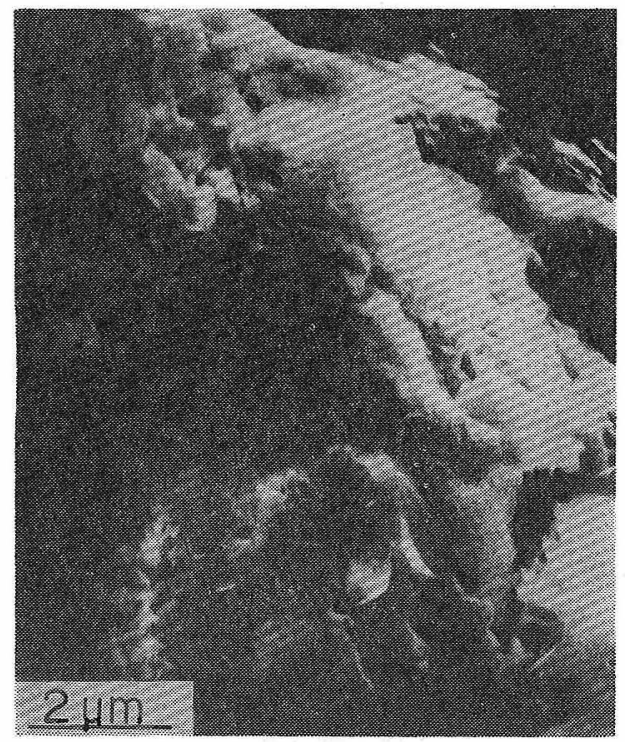

b)

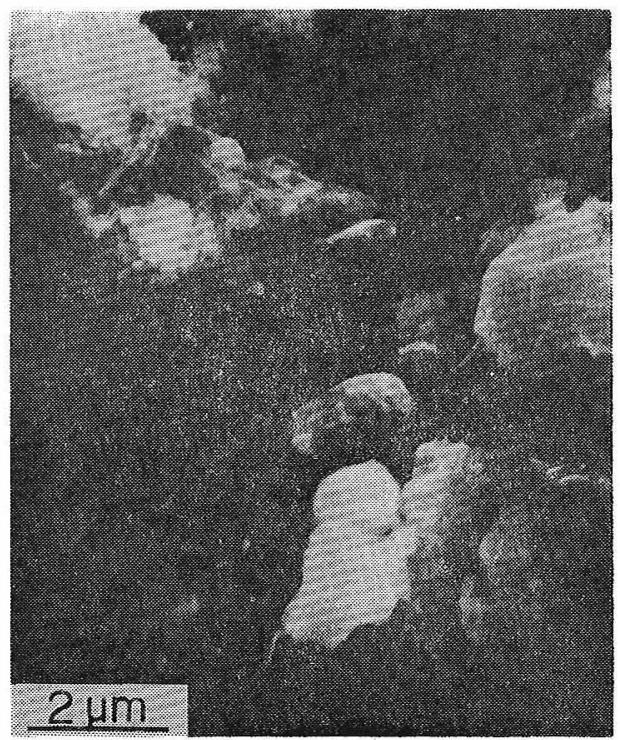

d)

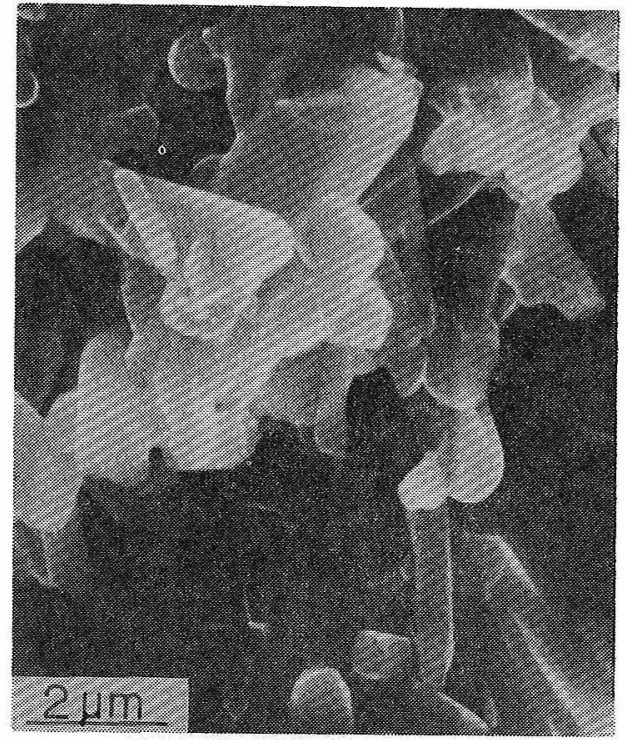

Fig. 2 Scanning electron micrographs of fracture surface. (a) nitrided at $1220^{\circ} \mathrm{C}$ up to $10 \%$, (b) nitrided at $1270^{\circ} \mathrm{C}$ up to $20 \%$, (c) nitrided at $14100^{\circ} \mathrm{C}$ up to $90 \%$, and (d) recrystallized $\beta-\mathrm{Si}_{8} \mathrm{~N}_{4}$ prepared by heating the sample similar to that shown in (c) at $1730^{\circ} \mathrm{C}$ for $8 \mathrm{~h}$ in $\mathrm{N}_{2}$.

were found around the grains (Fig. 3), and they showed that the reaction did not proceed uniformly on the grain surfaces.

Fig. 2-(b) shows the sample nitrided at $1270^{\circ} \mathrm{C}$. More reaction products were found than Fig. 2-(a). Fig. 2-(c) shows the sample nitrided at $1410^{\circ} \mathrm{C}$. In the sample, most part of raw silicon was nitrided and the fracture surface clearly differed from that in Fig. 2-(a) in appearance. Thin flakes were found with high magnification (Fig. 4).

$\mathrm{X}$-ray diffraction study showed that they were consisted of $\alpha-\mathrm{Si}_{3} \mathrm{~N}_{4}, \beta-\mathrm{Si}_{3} \mathrm{~N}_{4}$ and residual silicon. The ratio $\beta / \alpha$ was ca. $15 / 85$ and was nearly independent of nitriding temperature. The contents of
$\alpha-\mathrm{Si}_{3} \mathrm{~N}_{4}$ seemed to increase slightly with decreasing reaction temperature.

Fig. 2-(d) shows a fracture surface of $\beta-\mathrm{Si}_{3} \mathrm{~N}_{4}$ sample prepared by heating at $1730^{\circ} \mathrm{C}$ for $8 \mathrm{hr}$ in nitrogen gas of 1 atmospheric pressure ${ }^{5}$. Many prismatic microcrystals of $\beta-\mathrm{Si}_{3} \mathrm{~N}_{4}$ in the figure clearly indicated recrystallization ${ }^{6)}$.

\section{Discussion}

The results obtained in the earlier section seems to support the kinetics described in the introduction. They, however, are not sufficient to explaine grain size effect first reported by Hüttinger ${ }^{1)}$. Thompson and Pratt $^{3)}$ considered that the nitridation proceeded. 


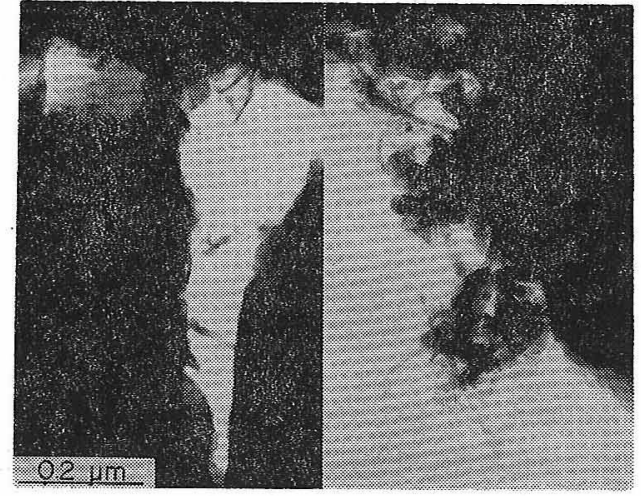

Fig. 3 Electron micrographs of powdered sample nitrided at $1220^{\circ} \mathrm{C}$ up to $10 \%$. Wide dark zones correspond to silicon grain.

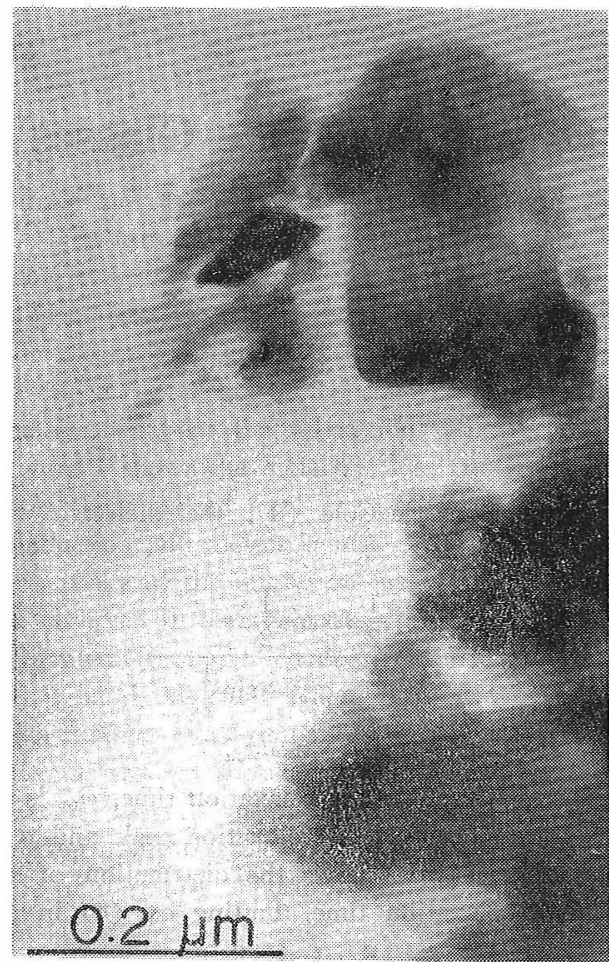

Fig. 4 Electron micrograph of powdered sample nitrided at $1410^{\circ} \mathrm{C}$ up to $90 \%$.

through cracking or exfoliation of very thin, said tens of $\AA$ thick, nitride films built on the surface of silicon particles by diffusion of nitrogen through the nitride films already formed; cracking and exfoliation were the results of volume increase of silicon nitride caused by nitridation at the interface between silicon and surface nitride skin.

Assume that the crack formation of the skin has an important role in the nitridation. As pointed out by Griffith, ${ }^{7)}$ the tensile strength $\sigma$ of a brittle material is controlled by the equation (1). Here $r$ is surface energy of the material, $E$ is elastic modulus and $c$ is the size of initial flaw from which catastrophic fracture initiates, and $A$ is a dimension less geometrical constant.

$$
\sigma=A(r \cdot E / c)^{1 / 2}
$$

The following thermodynamical relations ${ }^{8)}$ are obtained by introducing surface enthalpy $\Delta H_{\mathrm{sv}}$, lattice spacing $d$ of the nitride and the particle diameter $D$ of silicon,

$$
\begin{aligned}
& E \propto \Delta H_{\mathrm{sv}} / d \\
& r \propto \Delta H_{\mathrm{sv}}
\end{aligned}
$$

By assuming that $c$ is proportional to $D, \mathrm{Eq} .1$ is transformed into the following equation :

$$
\sigma \propto \Delta H H_{\mathrm{sv}} /(d \cdot D)^{1 / 2}
$$

As the lattice spacing $d$ is approximately constant, the following relation is obtained :

$$
\sigma \propto \Delta H_{\mathrm{sv}}{ }^{6} /(D)^{1 / 2} \text {. }
$$

If the thickness of the surface skin in which cracks extend is kept nearly constant ${ }^{2)}$ during the reaction, as the number of cracks formed in unit surface area is considered to be proportional to $1 / \sigma$, total length of the cracks in unit surface area is proportional to $(D)^{1 / 2}$ at constant temperature. Thus the reported results on the grain size effect is explained.

The activation energy of the reaction, 156 158 $\mathrm{kcal} / \mathrm{mol}^{12,2)}$ may correspond to that of diffusion process of nitrogen through the thin nitride skin. Because, the cracking or exfoliation are considered to be the results of the diffusion as stated earlier.

Clear difference in microstructure between Fig. $2-$ (c) and (d) suggest that the transformation $\alpha \rightarrow \beta$ might occur through recrystallization ${ }^{5}$. In the case of reaction between solid silicon and nitrogen, $\alpha-\mathrm{Si}_{3} \mathrm{~N}_{4}$ seems to be produced first and gradually recrystallize into $\beta-\mathrm{Si}_{3} \mathrm{~N}_{4}$ in prolonged reaction period. Mechanical strength of reaction sintered articles will be brought by the [recrystallization.

\section{Acknowledgment}

The author wishes to express his thanks to Mr. K. Sakaguchi and Mr. M. Tsutsumi for their kind cooperation in electron microscopy.

\section{References}

1) K.J. Hüttinger, High Temp. High Pressures, 1 [2] 221-30 (1969).

2) Y. Inomata and Y. Uemura, Yogyo-Kyokai-Shi 83 [5] 244-48 (1975).

3) D.S. Thompson and P.L. Pratt, "Science of Ceramics" p. 33-51 (Edited by G.H. Stewart, Academic Press, 1967).

4) H. Suzuki, Bulletin of the Tokyo Institute of Technology 54, 163-77 (1963).

5) Y. Inomata, Yogyo-Kyokai-Shi 82 [10] 522-26 (1974).

6) Y. Inomata and $Z$. Inoue, ibid. 81 [10] 441-44 (1973).

7) A.A. Griffith, Phil. Trans. Roy. Soc. London, 
Ser. A 221 [4] 163-98 (1920).

8) For example, R.A. Swalin, "Thermodynamics of
Solids" John Wiley and Sons, Inc. (1962).

[Received October 9,1974]

シリコン粉末の窒化

猪股吉 三

（科学技術庁 無機材質研究所）

シリコン粉末と窒素との反応で得られた生成物を電子 顕微鏡を用いて調べ，形態観察の結果を基に反応機構を 考察した. 反応の速度が，シリコン粒子径の平方根に比 例する事実は, Griffith の考え方を引用して 説明され た. 観察結果は，この反応の活性化エネルギー，156〜
$158 \mathrm{kcal} / \mathrm{mol}$ が，シリコン粒子表面に, 反応により形 成された窒化物皮膜中を窒素が拡散する際の障壁に相当 するものであるうとする考え方を支持するようなもので あった。

(10/9/1974 受付)

\title{
Measurements of Dielectric Relaxation in Oxide Glasses by Means of the Absorption Current Method
}

\author{
By \\ Hiroshi NAMIKAWA \\ (Materials Division, Electrotechnical Laboratory)
}

\section{Introduction}

So far it has been believed that there is no dielectric relaxation peak corresponding to the mixed alkali peak or the high temperature peak in the mechanical relaxation [1-4]. Recently, however, the distinct dielectric relaxation peak was observed in the mixed alkali glasses $[5,6]$, which show a remarkably small dielectric loss current compared with the conduction current. The present paper describes the application of the absorption current method based on Hamon-Nakajima's approximation $[7,8]$ to the measurement of the dielectric loss in oxide glasses exhibiting a very small dielectric loss current.

\section{Estimation of ratios of dielectric loss current to conduction current}

The dielectric loss current $J(\omega)$ and the conduction current $J_{0}$ are given by

$$
\begin{aligned}
& J(\omega)=\omega \bullet \varepsilon_{0} \cdot \varepsilon^{\prime \prime}(\omega) \cdot E \\
& J_{0}=\sigma \cdot E \quad \cdots \cdots \ldots \ldots \ldots \ldots \ldots \ldots
\end{aligned}
$$

where $\varepsilon^{\prime \prime}(\omega)$ is the dielectric loss factor at angular frequency $\omega(=2 \pi f), E$ is the field intensity. Therefore, the ratio $J(\omega) / J_{0}$ is given

$$
\frac{J(\omega)}{J_{0}}=\frac{\omega \cdot \varepsilon_{0} \cdot \varepsilon^{\prime \prime}(\omega)}{\sigma}
$$

According to Cole-Cole [9], the dielectric loss factor $\varepsilon^{\prime \prime}(\omega)$. is

$$
\begin{gathered}
\varepsilon^{\prime \prime}(\omega)=\frac{\frac{1}{2} \Delta \varepsilon \cdot \cos \frac{1}{2} \alpha \pi}{\cosh (1-\alpha) x+\sin \frac{1}{2} \alpha \pi} \\
x=\ln \omega \tau=\ln \omega / \omega_{\mathrm{m}}
\end{gathered}
$$

where $\tau$ is the dielectric relaxation time, $\omega_{\mathrm{m}}$ is the angular frequency at the relaxation peak and $\alpha$ is the parameter that shows the distribution of the dielectric relaxation time. Putting eq. (4) in (3) gives

$$
\frac{J(\omega)}{J_{0}}=\frac{\omega \cdot \varepsilon_{0} \cdot \Delta \varepsilon}{2 \sigma} \frac{\cos \frac{1}{2} \alpha \pi}{\cosh (1-\alpha) x+\sin \frac{1}{2} \alpha \pi}
$$

On the other hand, we have found $[5,6]$ the quantitative correlation between the conduction and the dielectric relaxation given by eq. (6)

$$
\sigma=p \cdot \varepsilon_{0} \cdot \Delta \varepsilon \cdot 2 \pi f_{\mathrm{m}}
$$

There are three types of diffusion processes characterized by the different correlation factors $p$ and which cause the conduction or the dielectric relaxation in different manners $[5,6]$. 